\title{
Assessing weeds at risk of evolving glyphosate resistance in Australian sub-tropical glyphosate-resistant cotton systems
}

\author{
Jeff Werth ${ }^{\mathrm{A}, \mathrm{C}}$, David Thornby ${ }^{\mathrm{A}}$, and Steve Walker ${ }^{\mathrm{B}}$ \\ ${ }^{A}$ Agri-Science Queensland, Department of Employment, Economic Development and Innovation, \\ Leslie Research Centre, 13 Holberton Street, Toowoomba, Qld 4350, Australia. \\ ${ }^{B}$ The University of Queensland, Queensland Alliance for Agriculture and Food Innovation, 13 Holberton Street, \\ Toowoomba, Qld 4350, Australia. \\ ${ }^{\mathrm{C}}$ Corresponding author. Email: jeff.werth@deedi.qld.gov.au
}

\begin{abstract}
Glyphosate resistance will have a major impact on current cropping practices in glyphosate-resistant cotton systems. A framework for a risk assessment for weed species and management practices used in cropping systems with glyphosate-resistant cotton will aid decision making for resistance management. We developed this framework and then assessed the biological characteristics of 65 species and management practices from 50 cotton growers. This enabled us to predict the species most likely to evolve resistance, and the situations in which resistance is most likely to occur. Species with the highest resistance risk were Brachiaria eruciformis, Conyza bonariensis, Urochloa panicoides, Chloris virgata, Sonchus oleraceus and Echinochloa colona. The summer fallow and non-irrigated glyphosate-resistant cotton were the highest risk phases in the cropping system. When weed species and management practices were combined, C. bonariensis in summer fallow and other winter crops were at very high risk. $S$. oleraceus had very high risk in summer and winter fallow, as did $C$. virgata and E. colona in summer fallow. This study enables growers to identify potential resistance risks in the species present and management practices used on their farm, which will to facilitate a more targeted weed management approach to prevent development of glyphosate resistance.
\end{abstract}

Additional keywords: glyphosate resistance, glyphosate-resistant cotton, risk assessment.

Received 2 August 2011, accepted 23 November 2011, published online 16 December 2011

\section{Introduction}

Glyphosate-resistant (GR) cotton was introduced in the Australian cotton industry in the 2000-01 season. Since then it has been widely adopted with $95 \%$ of cotton planted being GR in 2009-10. In-crop applications of glyphosate allowed improved control of some difficult-to-control weeds. The ability to substitute glyphosate for some conventional inputs, such as pre-emergence residual herbicides helped to reduce the risk of early-season damage and poor growth of cotton seedlings due to heavy rainfall concentrating the residuals in the seed zone (Charles et al. 1995). Both these factors have contributed to its rapid adoption. Even before the introduction of GR varieties, glyphosate was becoming commonly used for preplant knockdown applications, and shielded applications within the crop. Glyphosate use in fallow has largely replaced tillage, particularly in non-irrigated systems.

Glyphosate resistance has evolved in five weed species in the sub-tropical cropping region of north-east Australia - Lolium rigidum Gaud., Echinochloa colona (L.) Link, Urochloa panicoides P. Beauv., Conyza bonariensis (L.) Cronquist and Chloris truncata R.Br. (Heap 2011; Preston 2011). Effective management of these species to ensure their control is vitally important. However, as many cropping fields contain a diverse range of weed species, other species may also be at risk to evolving glyphosate resistance. Over 100 weed species have been identified in fields in this grain and cotton cropping region (Charles et al. 2004; Rew et al. 2005; Walker et al. 2005).

Clearly, however, not all weed species exposed to selection with glyphosate have so far developed glyphosate resistance. Several factors influence the evolution of herbicide resistance in weed populations. These are derived from genetic and biological characteristics of the weed species, and the management practices applied to the population (Powles and Yu 2010).

The species characteristics in particular that contribute to the evolution of herbicide resistance are gene mutation rate, initial frequency of resistance genes, inheritance, mating systems and gene flow (Jasieniuk et al. 1996). Although mutation rates and initial frequencies differ between herbicide modes of action (Maxwell and Mortimer 1994; Preston and Powles 2002; Neve et al. 2003), these frequencies are assumed to be similar between species, particularly in the construction of resistance models (Jasieniuk et al. 1996; Werth et al. 2008; Thornby and Walker 2009). 
Herbicide resistance will spread more rapidly in crosspollinated populations when associated with a single dominant allele (Maxwell and Mortimer 1994). However, selfing in a plant can increase the probability of the rate of evolution of resistance conferred by recessive alleles (Jasieniuk et al. 1996). The influence of mating behaviour (cross-pollinated or selfpollinated) on the evolution of resistance will depend on the nature of inheritance of resistance alleles (Jasieniuk et al. 1996).

Generation turnover is also a highly important factor in the rate of resistance evolution (Stanton et al. 2008). Eleusine indica (L.) Gaertner is a prolific seed producer and has four generations per year in Malaysia (Powles and Preston 2006), as a result glyphosate resistance evolved under persistent glyphosate usage in 3 years (Lee and Ngim 2000). This compares with L. rigidum in Australia, which evolved resistance after 15 years with one generation per year (Powles et al. 1998). The number of generations in each case was similar, 12 and 15, respectively. Although glyphosate was applied substantially more times per year on E. indica than L. rigidum, the frequent generation turnover also played a major role in the rate of resistance evolution.

Dense weed populations have a higher probability of developing resistance, even when the rate of mutation is low (Jasieniuk et al. 1996; Diggle et al. 2003). Species with high fecundity (either vegetatively, by seed or both) that have minimal seed dormancy tend to result in dense weed populations (Benech-Arnold et al. 2000).

Seed production of L. rigidum, E. colona, U. panicoides, and C. bonariensis can reach totals of over 30000, 12000,2000 and 100000 seeds/plant, respectively (Mercado and Talata 1977; Pannell et al. 2004; Wu et al. 2007; Werth et al. 2008). C. bonariensis has virtually no dormancy (Green et al. 2008), and although E. colona, U. panicoides, and L. rigidum have moderate levels of dormancy (Steadman et al. 2003; Kovach et al. 2010), they germinate at relatively specific times of the year, which often results in dense populations (Pannell et al. 2004; Werth 2007; Thornby and Walker 2009). This combined with persistent glyphosate use has resulted in them being selected for glyphosate resistance.

The other major determinant for resistance evolution is selection pressure. Species characteristics combined with continuous use of one or a few herbicides contributes to selection of resistance alleles (Maxwell and Mortimer 1994; Jasieniuk et al. 1996). Herbicide resistance appears where one or a few herbicides were used persistently to manage weeds (Preston and Rieger 2000; Stanton et al. 2008). Modelling has shown that using other herbicides as substituted for and in addition to glyphosate can delay resistance evolution (Diggle et al. 2003; Werth et al. 2008). Selection pressure for glyphosate resistance is a function of the frequency of glyphosate application and the frequency and effectiveness of other chemical and nonchemical kill methods such as tillage and crop competition (Thornby et al. 2010).

It is impractical for growers to monitor all weed species present in their fields. This has resulted in growers targeting a smaller number of key species and assuming that acceptable control will be achieved on the others. Determining which species are important often depends on several factors such as competitiveness with the crop, contamination of grain and lint, noxious weeds and aesthetics. Glyphosate resistance will increase the cost of weed control in addition to these factors. If we can identify species that are more prone to resistance evolution than others, growers can then concentrate their monitoring on those species to reduce the risk of glyphosate resistance evolving in their fields.

In this paper we describe the construction of a risk assessment framework for weeds likely to develop glyphosate resistance in farming systems with GR cotton. This assessment combined biological characteristics of 65 weed species with management practices used by 50 surveyed growers. The identified potential resistance risks derived from the species present in combination with the management practices used on their farm will enable growers to facilitate a more targeted and preventive weed management approach.

\section{Materials and methods}

The assessment framework consisted of two components: the biological characteristics of weed species and the management/ control practices applied to those species in farming systems with GR cotton grown in southern Queensland and northern New South Wales, Australia.

The risk assessment framework uses an expert systems approach, which is a method commonly used in basic decision support systems and management tools in a variety of fields. The approach has been used in many fields to provide tools for risk assessment and management, including pest (Potter et al. 2000) and weed management (Stigliani and Resina 1993; Monks et al. 1995; Wilkerson et al. 2002). Expert systems typically use a questioning or survey approach to gather information about an individual case, such as herbicide usage on weeds at a paddock level, from a non-expert user, and interpret the results using a series of statements or steps designed to reproduce the way a human expert would analyse them. The assessments used in expert systems may be based on interpreted data where available or, similarly to Bayesian belief networks, the consensus opinion of experts (Spiegelhalter et al. 1993). In our case we analysed a combination of real data, assumptions from existing resistance cases, and modelling (Werth et al. 2008; Thornby and Walker 2009) to produce a weighted scoring system. The framework uses our expertise-derived weightings to assess resistance risk for each weed or management scenario.

\section{Species risk}

Sixty-five species were included in the risk assessment as they were either named on glyphosate labels in Australia, known to have glyphosate resistance internationally, or found in various field surveys conducted in the northern grain region of Australia (Charles et al. 2004; Walker et al. 2005).

Species resistance potential was assessed using five main characteristics (Jasieniuk et al. 1996; Powles and Yu 2010). These were fecundity $\left(F_{i}\right)$, proportion of the viable seed bank that generally emerges $\left(P_{i}\right)$, ability to outcross $\left(M_{i}\right)$, method of reproduction $\left(S_{i}\right)$, and generation period $\left(T_{i}\right)$. The importance of these biological characteristics was determined by weighting categories using the expert systems approach (Table 1). For the purposes of this assessment it was assumed that resistance is nuclear, dominant and conferred by a single gene. This 
Table 1. Weed species characteristics and corresponding weightings used for the species risk assessment for evolution of glyphosate resistance

\begin{tabular}{|c|c|c|}
\hline Characteristic & Category & Weighting \\
\hline \multirow[t]{3}{*}{ 1. Fecundity } & $>100000$ seeds/plant & 10 \\
\hline & $10000-100000$ seeds/plant & 6 \\
\hline & 1000-10 000 seeds/plant & 3 \\
\hline \multirow[t]{3}{*}{ 2. Proportion of viable seed bank emerging } & Large with a single cohort & 10 \\
\hline & Large with multiple cohorts & 9 \\
\hline & Medium with a single cohort & 6 \\
\hline \multirow[t]{3}{*}{ 3. Mating } & Mostly selfing & 0.5 \\
\hline & Both selfing and outcrossing & 1 \\
\hline & Mostly outcrossing & 1 \\
\hline \multirow[t]{3}{*}{ 4. Reproduction method } & Sexual & 1 \\
\hline & Vegetative & 0.5 \\
\hline & Both & 1 \\
\hline
\end{tabular}

assumption was based on the fact that, in previous cases studied, a single gene confers glyphosate resistance (Lorraine-Colwill et al. 2001; Zelaya et al. 2004).

For each species $(i)$, categories were weighted, and added to form a score $R_{S_{i}}$, which is calculated as:

$$
R_{S_{i}}=F_{i}+P_{i}+M_{i}+S_{i}+T_{i}
$$

The scoring system for E. colona is demonstrated in Table 2. The theoretical maximum score achievable was 27, the species results were indexed against this maximum to produce a score out of 10 (as demonstrated in Table 2).

\section{Management risk}

The management risk associated with different parts of the crop rotation, $R_{M_{j}}$ (where $j$ is the phase or unit of the rotation i.e. summer fallow, or cotton crop etc.) is calculated as:

$$
R_{M_{j}}=G_{j}-\left(C_{j} * E_{C_{j}}\right)-\left(A_{j} * E_{A_{j}}\right)-K_{J}
$$

where $G_{j}$ is the number of glyphosate applications per phase $j, C_{j}$ is the number of times the grower attempts to control glyphosate survivors in phase $j, E_{C_{j}}$ is the average effectiveness of methods used to control survivors in phase $j ; A_{j}$ is the number of nonglyphosate kill methods used in phase $j$ and $E_{A_{j}}$ is for the average effectiveness of those alternatives. The values for $E_{C_{j}}$ and $E_{A_{j}}$ range from zero to 0.95 , this value was chosen as a maximum as it was considered quite difficult to achieve $100 \%$ control, particularly on a large scale.

$K_{j}$ is a crop rating, allowing for a reduction in weed seed set due to competitiveness of the crop use in phase $j, K_{j}$ is determined as:

$$
K_{j}=K_{F_{j}} * K_{R_{j}} * K_{D_{j}}
$$

where $K_{F}$ is a factor for the type of crop. For the range of rotational phases we studied, $K_{F}$ ranged from zero for fallow, (which has no competitive effect) to 0.6 for barley, (which has a high competitive effect) (Keeley and Thullen 1991; Lemerle et al. 1995; McGillon and Storrie 2006; Werth 2007; Wu et al. 2010). $K_{R_{j}}$ is a reducing factor for crop row spacing, and $K_{D_{j}}$ is a reducing factor for crop density. Total values for $K_{j}$ range between zero and 0.6 (Table 3).

\section{Overall risk}

The overall risk is determined by the species risk $R_{S_{i j}}$ and the level of selection pressure (management risk) exerted by the cropping system $R_{M_{i j}}$. Species were matched to relevant crops i.e. summer and winter except where growers indicated otherwise. A total risk

Table 2. Risk assessment scoring for Echinochloa colona using criteria in Table 1

\begin{tabular}{llr}
\hline Characteristic & Category & Weighting \\
\hline 1. Fecundity & $10000-100000$ seeds/plant & 6 \\
2. Proportion of viable seed bank emerging & Large with multiple cohorts & 9 \\
3. Mating & Mostly selfing & 0.5 \\
4. Reproduction method & Sexual & 1 \\
5. Generation period & Annual species with multiple generations per year on some seed produced & 2 \\
Total & & 18.5 \\
Indexed out of 10 & $(18.5 / 27) * 10$ & 6.9 \\
\hline
\end{tabular}


Table 3. Crop competition scoring factors used to determine impact of crop competition on management risk scores

\begin{tabular}{|c|c|c|c|c|c|}
\hline Crop & Competition factor & Row configuration ${ }^{\mathrm{A}}$ & Row configuration factor & Crop density ${ }^{\mathrm{B}}$ & Density factor \\
\hline Dryland cotton & 0.1 & Single skip & 0.9 & Medium & 0.9 \\
\hline Sunflowers & 0.1 & Super singles & 0.7 & - & - \\
\hline Maize & 0.2 & - & - & - & - \\
\hline Wheat & 0.4 & - & - & - & - \\
\hline Barley & 0.6 & - & - & - & - \\
\hline Fallow & 0 & - & - & - & - \\
\hline Other summer & 0.2 & - & - & - & - \\
\hline Other winter & 0.1 & - & - & - & - \\
\hline
\end{tabular}

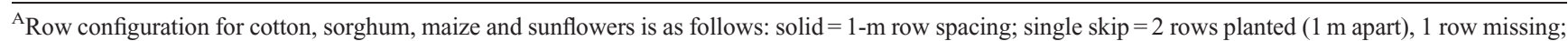
double skip $=2$ rows planted, 2 rows missing; super singles $=1$ row planted, 3 rows missing.

${ }^{\mathrm{B}}$ Crop density relative to accepted industry average.

score $R_{T_{i}}$ for weed species $i$ can then be calculated by multiplying the weed's species score by the average for phase $j$.

$$
R_{T_{i j}}=R_{S_{i}} * R_{M_{j}}
$$

\section{Grower information}

In a case study, 50 growers were surveyed to gain information of species present and management practices. Information gained was:

(1) Weed species present in crop and fallow;

(2) Crops grown, row configuration and planting density;

(3) Number of glyphosate applications in crop and fallow;

(4) Number of alternatives to glyphosate used in crop and fallow; and

(5) Number of times survivors of glyphosate application were controlled, and the effectiveness of those applications.

This information was used to form the management risk component of the assessment.

\section{Results}

Species risk

The indexed species risk scores ranged from 8.2 for Bracharia eruciformis (Sm.) Griseb. to 0.2 for Cyperus spp. The 20 highest scoring species are listed in Table 4. Four of the top 10 species currently have glyphosate-resistant populations in the sub-tropical cropping region of north-east Australia (C. bonariensis, 7.6; U. panicoides, 7.2; E. colona, 6.9; L. rigidum 6.3). The other glyphosate-resistant species in this region, C. truncata, scored 5.9. Eleusine indica (L.) Gaertn. and Sorghum halepense L. Pers., which have glyphosate-resistant populations worldwide, were ranked equal 7 th and 17 th with scores of 6.3 and 3.7, respectively. The lower 45 species not listed in Table 4 had scores less than 3 , and as a result are considered to have a low risk of evolving glyphosate resistance.

Other species in the top 20 that have evolved resistance to other herbicide groups include Avena spp. (ACCase inhibitors, ALS inhibitors), Hordeum spp. (ACCase inhibitors, Bipyridiliums),

Table 4. Species risk scores for the top 20 species identified as being at risk of evolving glyphosate resistance

\begin{tabular}{|c|c|c|c|}
\hline Species & Common name & Score & References for biological characteristics \\
\hline Brachiaria eruciformis & Sweet summer grass & 8.2 & - \\
\hline Conyza bonariensis & Flaxleaf fleabane & 7.6 & Wu et al. (2007) \\
\hline Urochloa panicoides & Liverseed grass & 7.2 & Werth et al. (2008) \\
\hline Chloris virgata & Feathertop Rhodes grass & 7.0 & Osten $(2008)$ \\
\hline Sonchus oleraceus & Sowthistle & 6.9 & Hutchinson et al. (1984); Widderick et al. (2010) \\
\hline Echinochloa colona & Awnless barnyard grass & 6.9 & Mercado and Talata (1977) \\
\hline Eleusine indica & Crowsfoot grass & 6.3 & Chin and Raja Harun (1980) \\
\hline Phalaris paradoxa & Paradoxa grass & 6.3 & Walker et al. (2001) \\
\hline Hordeum spp. & Barley grass & 6.3 & - \\
\hline Lolium rigidum & Annual ryegrass & 6.3 & Pannell et al. (2004) \\
\hline Dactyloctenium radulans & Button grass & 5.9 & - \\
\hline Digitaria ciliaris & Summer grass & 5.9 & Kobayashi and Oyanagi (2005) \\
\hline Chloris truncata & Windmill grass & 5.9 & - \\
\hline Amaranthus hybridus & Redshank & 4.8 & - \\
\hline Cirsium vulgare & Spear thistle & 4.8 & Sindel (1991); Suwa et al. (2010) \\
\hline Silybum marianum & Variegated thistle & 4.8 & Sindel (1991) \\
\hline Sorghum halepense & Johnson grass & 3.7 & Scopel et al. (1988); Vila-Aiub et al. (2007) \\
\hline Eragrostis cilianensis & Stink grass & 3.7 & - \\
\hline Avena spp. & Wild oats & 3.5 & Walker et al. (2001) \\
\hline Lactuca serriola & Prickly lettuce & 3.5 & - \\
\hline
\end{tabular}


Phalaris paradoxa L. (ACCase inhibitors), Sonchus oleraceus L. (ALS inhibitors), and Lactuca serriola L. (ALS inhibitors, Phenoxys) (Heap 2011). Species with herbicide-resistant populations that ranked lower than the highest 20 were Fallopia convolvulus (L.) A. Love, Raphanus raphanistrum L. and Sisymbrium thellungii O. Schultz all with scores of 1.9.

\section{Management risk}

Management risk scores averaged across all respondents ranged from 1.5 for non-irrigated GR cotton and summer fallow to 0.2 for irrigated non-GR cotton (Table 5), with the highest individual scores of 5 recorded for summer and winter fallows (one grower in each). Some growers reported applying up to 6 glyphosate applications per phase. These were recorded in GR cotton and winter fallows. Irrigated and non-irrigated GR cotton had the highest number of glyphosate applications with means of 3.2 and 3.0, respectively, and this was followed by the summer fallow which averaged 2.8 glyphosate applications. Irrigated GR cotton had the highest average number of applications to control glyphosate survivors (1.2) although some growers used five options to control glyphosate survivors in summer and winter fallows.

\section{Overall risk}

The combined total risk scores for each phase $\left(R_{T_{i j}}\right)$ are listed in Table 6 . The weed species and phase with the highest risk was $B$. eruciformis in non-irrigated GR cotton (12.3) and summer fallow (12.0). This was followed by $C$. bonariensis also in nonirrigated GR cotton (11.5) and summer fallow (11.2). When species present and management practices were combined for individual responses, $C$. bonariensis in summer fallow and other winter crops had very high risk situations (0-30). S. oleraceus had

Table 5. Management risk scores by phase for number of glyphosate applications, control of survivors of glyphosate applications, use of alternatives to glyphosate and the total management risk score $\left(R_{M_{i}}\right)$ Scores are means followed by range in parentheses

\begin{tabular}{lccccc}
\hline Phase & $\begin{array}{c}\text { No. of } \\
\text { responses }\end{array}$ & $\begin{array}{c}\text { Glyphosate } \\
\text { applications }\left(G_{j}\right)\end{array}$ & $\begin{array}{c}\text { Survivor } \\
\text { control }\left(C_{j}\right)\end{array}$ & $\begin{array}{c}\text { Number of } \\
\text { alternatives }\left(A_{j}\right)\end{array}$ & Total $\left(R_{\left.M_{j}\right)}\right)$ \\
\hline Summer fallow & 31 & $2.8(0-5)$ & $0.7(0-5)$ & $1.1(0-3)$ & $1.5(0-5)$ \\
Non-irrigated GR cotton & 11 & $3.0(2-6)$ & $1.0(0-3)$ & $1.3(0-7)$ & $1.5(0-4)$ \\
Non-irrigated non-GR cotton & 1 & 2 & 1 & $0.5(0-1)$ & 1.4 \\
Winter fallow & 30 & $2.1(0-6)$ & $0.6(0-5)$ & $0.5(0-3)$ & $1.2(0-5)$ \\
Irrigated GR cotton & 22 & $3.2(2-6)$ & $1.2(0-4)$ & $1.1(0-4)$ & $1.1(0-4)$ \\
Other winter crop & 22 & $1.6(0-4)$ & $0.5(0-3)$ & $1.1(0-3)$ & $0.8(0-4)$ \\
Sorghum & 22 & $2.0(0-5)$ & $0.5(0-2)$ & $1.6(0-4)$ & $0.6(0-4)$ \\
Wheat & 32 & $1.3(0-4)$ & $0.5(0-3)$ & $0.9(0-3)$ & $0.5(0-4)$ \\
Barley & 14 & $1.0(0-3)$ & $0.3(0-1)$ & $0.9(0-3)$ & $0.5(0-3)$ \\
Other summer crop & 11 & $1.2(0-3)$ & $0.6(0-2)$ & $0.7(0-3)$ & $0.4(0-1)$ \\
Irrigated non-GR cotton & 7 & $1.3(0-2)$ & $0.6(0-2)$ & $1.6(0-6)$ & $0.2(0-2)$ \\
\hline
\end{tabular}

Table 6. Mean total risk scores $\left(R_{T_{i j}}\right)$ for highest risk weeds and phases

Maximum individual risk scores are indicated in parentheses (all individual risk scores had minimum values of zero). Single dashes in predicted total risk scores indicate an unlikely combination for which no estimate is made

\begin{tabular}{|c|c|c|c|c|c|c|c|c|c|c|c|}
\hline Species & $\begin{array}{l}\text { Summer } \\
\text { fallow }\end{array}$ & $\begin{array}{c}\text { Non- } \\
\text { irrigated } \\
\text { GR cotton }\end{array}$ & $\begin{array}{c}\text { Non- } \\
\text { irrigated } \\
\text { non-GR cotton }\end{array}$ & $\begin{array}{l}\text { Winter } \\
\text { fallow }\end{array}$ & $\begin{array}{l}\text { Irrigated } \\
\text { GR cotton }\end{array}$ & $\begin{array}{l}\text { Other } \\
\text { winter } \\
\text { crop }\end{array}$ & Sorghum & Wheat & Barley & $\begin{array}{l}\text { Other } \\
\text { summer } \\
\text { crop }\end{array}$ & $\begin{array}{c}\text { Irrigated } \\
\text { non-GR } \\
\text { cotton }\end{array}$ \\
\hline \multicolumn{12}{|c|}{ Predicted total risk (mean management risk per phase $\times$ species risk) } \\
\hline Brachiaria eruciformis & 12 & 12.3 & 11.4 & 9.8 & 9.2 & - & 5.2 & - & - & 3 & 1.7 \\
\hline Conyza bonariensis & $11.2(30)$ & $11.5(22)$ & $10.6(14)$ & $9.2(23)$ & $8.6(21)$ & $6.4(30)$ & 4.9 (17) & 3.7 & $3.8(16)$ & $2.8(6)$ & $1.6(14)$ \\
\hline Urochloa panicoides & $10.7(22)$ & $10.9(21)$ & 10.1 & $8.7(11)^{\mathrm{A}}$ & $8.1(21)$ & $6.1(22)^{\mathrm{A}}$ & $4.6(16)$ & - & - & $2.7(7)$ & $1.5(2)$ \\
\hline Chloris virgata & $10.4(28)$ & $10.6(7)$ & 9.9 & $8.5(15)^{\mathrm{A}}$ & 7.9 & - & $4.5(6)$ & - & - & 2.6 & 1.5 \\
\hline Sonchus oleraceus & $10.1(28)$ & $10.4(7)$ & 9.6 & $8.3(28)$ & $7.7(14)$ & $5.8(27)$ & $4.4(6)$ & $3.4(14)$ & $3.4(17)$ & $2.6(1)$ & 1.4 \\
\hline Echinochloa colona & $10.1(27)$ & $10.4(27)$ & 9.6 & $8.3(21)^{\mathrm{A}}$ & $7.7(27)$ & $5.8(21)^{\mathrm{A}}$ & $4.4(15)$ & - & $3.4(17)^{\mathrm{A}}$ & $2.6(7)$ & $1.4(2)$ \\
\hline Eleusine indica & 9.3 & 9.5 & 8.8 & - & 7.1 & - & 4 & - & - & 2.3 & 1.3 \\
\hline Phalaris paradoxa & 9.3 & - & - & 7.6 & - & 5.3 & - & 3.1 & 3.1 & - & - \\
\hline Hordeum sp. & 9.3 & - & - & 7.6 & - & 5.3 & - & 3.1 & 3.1 & - & - \\
\hline Lolium rigidum & $9.3(7)$ & - & - & 7.6 & - & $5.3(12)$ & - & 3.1 & 3.1 & - & - \\
\hline Dactyloctenium radulans & $8.7(24)$ & 9 & 8.3 & 7.1 & 6.7 & 5 & 3.8 & 2.9 & 2.9 & 2.2 & 1.2 \\
\hline Digitaria ciliaris & $8.7(24)$ & 9 & 8.3 & $7.1(12)$ & 6.7 & 5 & $3.8(13)$ & 2.9 & 2.9 & 2.2 & 1.2 \\
\hline Chloris truncata & $8.7(24)$ & $9.0(6)$ & 8.3 & $7.1(9)$ & $6.7(12)$ & 5 & $3.8(5)$ & 2.9 & 2.9 & 2.2 & $1.2(1)$ \\
\hline
\end{tabular}

$\overline{{ }^{\mathrm{A}} U \text {. panicoides, E. colona and C. virgata are not generally considered to be winter weeds; however, some growers indicated they were present in some winter crops }}$ and fallow. 
very high risk situations in summer and winter fallow (0-28), as $\operatorname{did} C$. virgata and E. colona in summer fallow (0-28). The range of grower individual scores varied. For example, the industry mean for $C$. bonariensis in other winter crops was only 6.4 compared with an individual response of 30. This highlights the wide range of management practices adopted by growers throughout the industry. The summer fallow in general had higher risks for all species when compared with other phases. The use of alternatives and survivor control in the summer fallow was generally less than both irrigated and non-irrigated GR cotton.

\section{Discussion}

Species at risk

All species with confirmed glyphosate resistance in the sub-tropical cropping region of Australia, C. bonarensis, E. colona, U. panicooides, L. rigidum and C. truncata, were present within the top 10 species and had species risk scores 5.9 or above. This is a good indication of the usefulness of our risk assessment process.

There are five species in the top 10 that are currently not confirmed with glyphosate resistance in this region $B$. eruciformis, $S$. oleraceus, $C$. virgata, E. indica and Hordeum species. B. eruciformis is common in central Queensland and is a high risk species for that region (Osten et al.2007), but not found in the cotton-growing areas of southern Queensland and northern New South Wales. Our survey did not include central Queensland and thus no overall risk scores were calculated for that species.

S. oleraceus is a common weed across the sub-tropical cropping region and has the ability to germinate all year round. Although $S$. oleraceus has virtually no dormancy (Chauhan et al. 2006; Widderick et al. 2010), it is rarely present in the field in dense populations. Fallows infested with $S$. oleraceus are normally treated with mixtures of glyphosate and 2,4-D (Walker et al. 2005). This combination with different modes of action (Groups M and I) would be expected to reduce the risk of glyphosate resistance evolution. Thus, it is likely that the lower average population density and less exposure to glyphosate alone are reasons why glyphosate resistance has not yet been observed in this species.

C. virgata is a species that is a major problem in central Queensland (Osten 2008) but is increasing in prevalence in north-eastern Australian cropping systems. This species is not particularly susceptible to glyphosate and current practices may have led to a species shift rather than evolved resistance, though in both cases the effectiveness of glyphosate is reduced.

E. indica and Dactyloctenium radulans (R.Br.) Beauv. are both not widespread (Charles et al. 2004; Walker et al. 2005), and as a result are not considered major resistance issues for the industry as a whole. Even so, if present in the field, they require particular attention, particularly as populations of $E$. indica are glyphosate-resistant overseas.

The top 20 species are dominated by the annual grasses and members of the Asteraceae family. This is predominately due to their high seed production, which is a common characteristic of current resistant species. Therefore, these are the species that growers need to monitor closely.

\section{Risks in crops and fallows}

Within the diverse cropping systems of the Australian subtropical region, the high risk phases were non-irrigated GR cotton, summer fallow, and to a lesser extent irrigated GR cotton. This assessment confirmed previous perceived risks and again indicates the usefulness of our risk assessment process.

However, the overall risk was highly dependent on the weed species present in the different phases of the rotation. As an example, the average risk for 'other' winter crops was approximately half of that for summer fallow and non-irrigated GR cotton. However, when $C$. bonariensis was present in the 'other' winter crops phase, individual risks were the same as for the summer fallow (both 30), and higher than non-irrigated GR cotton (22).

Eleven of the 50 surveyed growers indicated that they grew non-irrigated GR cotton. In this phase, the risks for $C$. bonariensis, $U$. panicoides and E. colona were high. Currently there is only one confirmed resistant E. colona population in a non-irrigated GR cotton system (Werth et al. 2010), though the number of cases is likely to increase. It is concerning that there were growers, who indicated they did not control survivors of glyphosate application, despite the requirements to do so (Werth et al. 2008). These growers are likely to have thought that glyphosate provided sufficient control negating the need for further action. The individual responses of non-irrigated GR cotton growers did, however, indicate that they all used an alternative to glyphosate at some stage, and thus no grower in this survey relied on glyphosate only for weed control.

The risk scores for the summer fallow were consistently high. Glyphosate has been relied upon for weed control in the summer fallow phase for several years. It is unclear if the survivor control in the fallows were separate applications specifically for controlling glyphosate survivors, or if they were included in other herbicide applications. Tank-mix partners such as 2,4-D, picloram and MCPA do not act as alternatives for grass control. Therefore, research now concentrates on strategic use of residual herbicides and tillage to reduce the reliance on glyphosate. In fallow situations, Group A herbicides (ACCase inhibitors) are starting to be used. These herbicides have a high resistance risk, and as a result, the impact of their increased use in fallow needs to be examined thoroughly before promotion to growers.

\section{Conclusions}

Overall, the individual and average risks for glyphosate resistance in cotton systems of sub-tropical Australia vary considerably. This highlights the importance for growers to individually assess their own situation in terms of species present and their management practices. Our risk assessment framework will enable growers to tailor their weed management to focus on those species that are at a high risk of evolving resistance. They will need to use effective alternatives to glyphosate, which when targeted at their at-risk weed species will help to ensure the longterm sustainability of glyphosate.

\section{Acknowledgements}

This research was funded by the Cotton Catchment Communities Cooperative Research Centre, the Cotton Research and Development Corporation and Monsanto Australia Ltd. 


\section{References}

Benech-Arnold RL, Sanchez RA, Forcella F, Kruk BC, Ghersa CM (2000) Environmental control of dormancy in weed seed banks in soil. Field Crops Research 67, 105-122. doi:10.1016/S0378-4290(00)00087-3

Charles G, Taylor I, Roberts G (2004) The impact of the cotton farming system on weed succession: implications for herbicide resistance and adoption of an integrated weed management approach. In '14th Australian Weeds Conference'. Wagga Wagga, NSW. (Eds BM Sindel, SB Johnson) pp. 410-413. (Weed Society of New South Wales: Sydney)

Charles GW, Constable GA, Kennedy IR (1995) Current and future weed control practices in cotton: the potential use of transgenic herbicide resistance. In 'Herbicide-resistant crops and pastures in Australian farming systems'. (Eds GD McLean, G Evans) pp. 89-100. (Bureau of Resource Sciences: Parkes, ACT)

Chauhan BS, Gill G, Preston C (2006) Factors affecting seed germination of annual sowthistle (Sonchus oleraceus) in southern Australia. Weed Science 54, 854-860. doi:10.1614/WS-06-047R.1

Chin HF, Raja Harun RM (1980) Ecology and physiology of Eleusine indica seeds. In 'Proceedings of the 7th Asian-Pacific Weed Science Society Conference'. Sydney, NSW, 1979. pp. 313-315.

Diggle AJ, Neve PB, Smith FP (2003) Herbicides used in combination can reduce the probability of herbicide resistance in finite weed populations. Weed Research 43, 371-382. doi:10.1046/j.1365-3180. 2003.00355.x

Green TD, Sindel BM, Charles G, Werth J (2008) A review of the ecology of fleabane (Conyza spp.). In 'Proceedings of the 16th Australian Weeds Conference'. Cairns, Queensland, 18-22 May 2008. (Eds RD van Klinken, VA Osten, FD Panetta, JC Scanlan) pp. 171-173. (Queensland Weeds Society: Brisbane)

Heap I (2011) International survey of herbicide resistant weeds. Available online at: www.weedscience.com (accessed 6 January 2011).

Hutchinson I, Colosi J, Lewin RA (1984) The biology of Canadian weeds. 63. Sonchus asper (L.) Hill and Sonchus oleraceus L. Canadian Journal of Plant Science 64, 731-744. doi:10.4141/cjps84-100

Jasieniuk M, Brule-Babel AL, Morrison IN (1996) The evolution and genetics of herbicide resistance in weeds. Weed Science 44, 176-193.

Keeley PE, Thullen RJ (1991) Growth and interaction of barnyardgrass (Echinochloa crus-galli) with cotton (Gossypium hirsutum). Weed Science 39, 369-375.

Kobayashi H, Oyanagi A (2005) Digitaria ciliaris seed banks in untilled and tilled soybean fields. Weed Biology and Management 5, 53-61. doi:10.1111/j.1445-6664.2005.00156.x

Kovach DA, Widrlechner MP, Brenner DM (2010) Variation in seed dormancy in Echinochloa and the development of a standard protocol for germination testing. Seed Science and Technology 38, 559-571.

Lee LJ, Ngim J (2000) A first report of glyphosate-resistant goosegrass [Eleusine indica (L) Gaertn] in Malaysia. Pest Management Science 56, 336-339. doi:10.1002/(SICI)1526-4998(200004)56:4<336::AIDPS123>3.0.CO;2-8

Lemerle D, Verbeek B, Coombes N (1995) Losses in grain yield of winter crops from Lolium rigidum competition depend on crop species, cultivar and season. Weed Research 35, 503-509. doi:10.1111/j.1365-3180.1995. tb01648.x

Lorraine-Colwill DF, Powles SB, Hawkes TR, Preston C (2001) Inheritance of evolved glyphosate resistance in Lolium rigidum (Gaud.). Theoretical and Applied Genetics 102, 545-550. doi:10.1007/ s001220051680

Maxwell BD, Mortimer AM (1994) Selection for herbicide resistance. In 'Herbicide resistance in plants'. (Eds SB Powles, JAM Holtum) pp. 1-26. (Lewis Publishers: Boca Raton, FL)

McGillon T, Storrie A (Eds) (2006) 'Integrated weed management in Australian cropping systems - a training resource for farm advisors.' (CRC for Australian Weed Management: Adelaide)
Mercado BL, Talata RL (1977) Competitive ability of Echinochloa colonum L. against direct-seeded lowland rice. In '6th Asia-Pacific Weed Science Society Conference'. Indonesia. pp. 161-165. (AsiaPacific Weed Science Society)

Monks CD, Bridges DC, Woodruff JW, Murphy TR, Berry DJ (1995) Expert system evaluation and implementation for soybean (Glycine max) weed management. Weed Technology 9, 535-540.

Neve P, Diggle AJ, Smith FP, Powles SB (2003) Simulating evolution of glyphosate resistance in Lolium rigidum I: population biology of a rare resistance trait. Weed Research 43, 404-417. doi:10.1046/j.00431737.2003.00358.x

Osten V (2008) 'Managing feathertop Rhodes grass: a best weed management guide.' (Department of Employment, Economic Development and Innovation: Brisbane, Qld)

Osten VA, Walker SR, Storrie A, Widderick M, Moylan P, Robinson GR, Galea K (2007) Survey of weed flora and management relative to cropping practices in the north-eastern grain region of Australia. Australian Journal of Experimental Agriculture 47, 57-70. doi:10.1071/ EA05141

Pannell DJ, Stewart V, Bennett A, Monjardino M, Schmidt C, Powles SB (2004) RIM: a bioeconomic model for integrated weed management of Lolium rigidum in Western Australia. Agricultural Systems 79, 305-325. doi:10.1016/S0308-521X(03)00089-1

Potter WD, Deng X, Li J, Xu M, Wei Y, Lappas I, Twery MJ, Bennett DJ (2000) A web-based expert system for gypsy moth risk assessment. Computers and Electronics in Agriculture 27, 95-105. doi:10.1016/ S0168-1699(00)00100-9

Powles SB, Lorraine-Colwill DF, Dellow JJ, Preston C (1998) Evolved resistance to glyphosate in rigid ryegrass (Lolium rigidum) in Australia. Weed Science 46, 604-607.

Powles SB, Preston C (2006) Evolved glyphosate resistance in plants: biochemical and genetic basis of resistance. Weed Technology 20, 282-289. doi:10.1614/WT-04-142R.1

Powles SB, Yu Q (2010) Evolution in action: plants resistant to herbicides. Annual Review of Plant Biology 61, 317-347. doi:10.1146/annurevarplant-042809-112119

Preston C (2011) Australian glypohsate resistance register: summary. Available at: www.glyphosateresistance.org (accessed 18 April 2011).

Preston C, Powles SB (2002) Evolution of herbicide resistance in weeds: initial frequency of target site-based resistance to acetolactate synthaseinhibiting herbicides in Lolium rigidum. Heredity 88, 8-13. doi:10.1038/ sj.hdy.6800004

Preston C, Rieger MA (2000) Managing herbicide resistance in weeds from use of herbicide tolerant crops. Plant Protection Quarterly 15, $77-79$.

Rew LJ, Medd RW, Van de Ven R, Gavin JJ, Robinson GR, Tuitee M, Barnes J, Walker S (2005) Weed species richness, density and relative abundance on farms in the subtropical grain region of Australia. Australian Journal of Experimental Agriculture 45, 711-723. doi:10.1071/EA03273

Scopel AL, Ballare CL, Ghersa CM (1988) Role of seed reproduction in the population ecology of Sorghum halepense in maize crops. Journal of Applied Ecology 25, 951-962. doi:10.2307/2403757

Sindel BM (1991) A review of the ecology and control of thistles in Australia. Weed Research 31, 189-201. doi:10.1111/j.1365-3180.1991.tb01758.x

Spiegelhalter DJ, Dawid AP, Lauritzen SL, Cowell RG (1993) Bayesian analysis in expert systems. Statistical Science 8, 219-247. doi:10.1214/ss/ 1177010888

Stanton RA, Pratley JE, Hudson D, Dill GM (2008) A risk calculator for glyphosate resistant in Lolium rigidum (Gaud.). Pest Management Science 64, 402-408. doi:10.1002/ps.1511

Steadman KJ, Bignell GP, Ellery AJ (2003) Field assessment of thermal after-ripening time for dormancy release prediction in Lolium rigidum seeds. Weed Research 43, 458-465. doi:10.1046/j.0043-1737.2003. 00363.x 
Stigliani L, Resina C (1993) SELOMA: expert system for weed management in herbicide-intensive crops. Weed Technology 7, 550-559.

Suwa T, Louda SM, Russell FL (2010) No interaction between competition and herbivory in limiting introduced Cirsium vulgare rosette growth and reproduction. Oecologia 162, 91-102. doi:10.1007/s00442-009$1432-8$

Thornby DF, Walker SR (2009) Simulating the evolution of glyphosate resistance in grains farming in northern Australia. Annals of Botany 104, 747-756. doi:10.1093/aob/mcp 152

Thornby D, Werth J, Curr M, Walker S (2010) Risks and RATs: assessing glyphosate resistance risk in paddocks in north-eastern Australia. In '17th Australiasian Weeds Conference'. Christchurch, NZ. (Ed. SM Zydenbos) pp. 246-249. (New Zealand Plant Protection Society: Christchurch)

Vila-Aiub MM, Balbi MC, Gundel PE, Ghersa CM, Powles SB (2007) Evolution of glyphosate-resistant Johnsongrass (Sorghum halepense) in glyphosate-resistant soybean. Weed Science 55, 566-571. doi:10.1614/WS-07-053.1

Walker SR, Robinson GR, Medd RW (2001) Management of Avena ludoviciana and Phalaris paradoxa with barley and less herbicide in subtropical Australia. Australian Journal of Experimental Agriculture 41, 1179-1185. doi:10.1071/EA01002

Walker SR, Taylor IN, Milne G, Osten VA, Hoque Z, Farquharson RJ (2005) A survey of management and economic impact of weeds in dryland cotton cropping systems of subtropical Australia. Australian Journal of Experimental Agriculture 45, 79-91. doi:10.1071/EA03189

Werth JA (2007) Weed resistance risk management in glyphosate-resistant cotton. PhD Thesis, University of Adelaide, SA, Australia.
Werth JA, Preston C, Taylor IN, Charles GW, Roberts GN, Baker J (2008) Managing the risk of glyphosate resistance in Australian glyphosateresistant cotton production systems. Pest Management Science 64, 417-421. doi:10.1002/ps.1508

Werth J, Thornby D, Walker S, Charles G, McDonald C (2010) Species shift and resistance: challenges for Australian cotton systems. In '17th Australasian Weeds Conference'. Christchurch, NZ. (Ed. SM Zydenbos) pp. 20-23. (New Zealand Plant Protection Society: Christchurch)

Widderick MJ, Walker SR, Sindel BM, Bell KL (2010) Germination, emergence, and persistence of Sonchus oleraceus, a major crop weed in subtropical Australia. Weed Biology and Management 10, 102-112. doi:10.1111/j.1445-6664.2010.00370.x

Wilkerson GG, Wiles LJ, Bennett AC (2002) Weed management decision models: pitfalls, perceptions, and possibilities of the economic threshold approach. Weed Science 50, 411-424. doi:10.1614/0043-1745(2002)050 [0411:WMDMPP]2.0.CO;2

Wu H, Walker S, Rollin MJ, Tan DKY, Robinson G, Werth J (2007) Germination, persistence, and emergence of flaxleaf fleabane [Conyza bonariensis (L.) Cronquist]. Weed Biology and Management 7, 192-199. doi:10.1111/j.1445-6664.2007.00256.x

Wu HW, Walker SR, Osten VA, Robinson G (2010) Competition of sorghum cultivars and densities with Japanese millet (Echinochloa esculenta). Weed Biology and Management 10, 185-193. doi:10.1111/j.14456664.2010.00383.x

Zelaya IA, Owen MDK, VanGessel MJ (2004) Inheritance of evolved glyphosate resistance in Conyza canadensis (L.) Cronq. Theoretical and Applied Genetics 110, 58-70. doi:10.1007/s00122-004-1804-8 